\title{
Could New Accounting Directive Improve European Financial Reporting?
}

Dear readers,

over more than thirty years, European regulation of financial reporting is realized by accounting Directives, namely the EC 4th and 7th Directive (78/660/EEC and 83/349/EEC). The Directives have been amended several times, but they have not been subject to a fundamental revision since their issue. New requirements, such as new disclosures and valuation rules, including detailed provisions on fair value accounting, have been added. Requirements have made the Directives difficult to read. Directives haven't provide the same level of detail concerning different accounting areas. Moreover many options make comparisons of national financial statements from different Member States difficult. As follows from different European procedures, based on research studies, like "Communication on a simplified business environment for companies in the areas of company law, accounting and auditing" and "Project on baseline measurement and reduction of administrative costs", less attention has been paid to consider whether existing requirements could be simplified or removed. Mentioned studies confirm that amendments have tended to ignore the comparability and usefulness of the financial statements, increased reporting requirements and the number of Member State options. All these facts have ultimately, in the long run, led to increased complexity and regulatory burden for all companies. As confirm other EC Communication from 2008, shortly described as „Think Small First", this increased burden bears down primarily on smaller companies. The Europe 2020 Strategy aims to make the EU a smarter, more sustainable and inclusive economy. The strategy aims to simplify life for SMEs, which represent up more than 99\% of Europe's businesses, and to improve these companies' access to finance.

Comparability of accounting information at EU level needed to be improved. Works on modernization, improvements and better comprehensibility of Directives have been finalized this year in the form of newly issued Directive. Directive 2013/34/EU of the European Parliament has been published by European Union EU which covers annual financial statements and consolidated financial statements. This Directive also considered amending Directive 2006/43/EC of the 
European Parliament and of the Council and repealing EC 4th and 7th Council Directives. New thresholds giving rise to four types of undertakings/groups: micro-undertakings, small undertakings or group, medium-sized undertakings or group, large undertakings or group. There is no EU requirement for small companies to have an audit.

The Directive incorporates Directive 2012/6/EU on micro-entities, allowing micro-entities to prepare a very simple balance sheet and profit and loss account with virtually no notes. The Directive also simplifies the preparation of financial statements for small undertakings and groups by reducing and limiting the amount of information to be provided in the notes to the financial statements. Some changes are less restrictive, especially for small undertakings. However, for medium sized and large undertakings or groups, as well as for public-interest entities, the changes like post balance sheet events could become more constraining. Other key changes were introduced into the new Directive: materiality principle (aggregation of accounting information in financial statements if such information is considered as immaterial); definition of control has been extended (dominant influence, control without any shares in the subsidiary); potential consolidation exemption for medium-sized group (exempt for public interest entity). Accounting requirements are simplified and reduced from small and medium-sized private owned companies. Reduced or simplified requirements are not applied for public interest entities.

The annual financial statements shall comprise, as a minimum, the balance sheet, the profit and loss account and the notes to the financial statements. Member States may require accounting entities other than small ones to include other statements in the annual financial statements in addition to the balance sheet, the profit and loss account and the notes to the financial statements. The Directive does not require preparation of a cash flow statement. The annual financial statements shall give a true and fair view of the undertaking's assets, liabilities, financial position and profit or loss. Where the application of this Directive would not be sufficient to give a true and fair view of the entities' assets, liabilities, financial position and profit or loss, such additional information as is necessary to comply with that requirement shall be given in the notes to the financial statements.

As there were many cross-references between the EC 4th and 7th Directive, merging them is a logical step. Moreover, during consultations 
with national representatives and public, there was a support for such a measure on the grounds that it would provide clarity, consistency and coherence to the accounting framework for non-listed companies. As most Member States have already adopted an option into their national legislation that exempts small groups from preparing consolidated financial statements. Therefore the Directive confirms this approach and exempt small groups from preparing consolidated financial statements.

Merging the EC 4th and 7th Directive, "think small first" approach in the building of merged Directive together with its comprehensibility reflected in the new Directive makes this EU legislation better adapted to the present and future needs of prepares and users of accounting information in financial statements.

\author{
doc. Ing. Marcela Žárová, CSc. \\ Vice-dean for Foreign Relations \\ Faculty of Finance and Accounting, \\ University of Economics, Prague
}

